\title{
Tick attachment sites in humans living in the Tokat province of Turkey
}

\author{
Tokat ilinde yaşayan insanlardaki kene tutunma bölgelerinin \\ değerlendirilmesi
}

\author{
Adem KESKiN ${ }^{1}$, Yunus Emre BULUT ${ }^{2}$, Aysun KESKiN¹, Ahmet BURSALI ${ }^{1}$
}

\section{ABSTRACT}

Objective: The aim of this study was to evaluate the attachment sites of ticks and the demographic properties of patient infested by ticks in Tokat province, a Crimean-Congo hemorrhagic fever (CCHF) endemic region in Turkey.

Methods: In 2009, 5,089 patients with tick bites admitted to hospitals of Tokat province. A standard questionnaire, including the name, age, gender, profession, date, living area, and travel history of patients, was filled by health personals for each patient with a tick bite. Attachment sites of ticks were divided into 9 groups: abdomen, arms, axilla, back, chest, head and neck, hip, legs, and perineum, while the age-group of patients were as follows: 0-9, 10-19, 20-39, 40-64 and $\geq 65$.

Results: The majority of the patients applied $(n=1,051,23.3 \%)$ were found ticks on the legs of them. 20-39 year age group tick-infested were the highest proportion ( $n=1228,27.24 \%)$, while 2,825 (62.67\%) of patients were male, and 1,683 (37.33\%) were female. In addition, it was determined that 2,740 (60.78\%) of patients were living in rural, while 1,768 (39.22\%) were living in urban areas. A total of 20 tick taxa were identified, comprising 6 genera: Argas (1 species), Dermacentor (2 species), Haemaphysalis (3 species and

\section{ÖZET}

Amaç: Bu çalıșmada, Türkiye'de Kırım Kongo Kanamalı Ateși (KKKA) açısından endemik olan bir bölgede kene enfestastonu olan kişilerin demografik özelliklerinin ve kenelerin tutunma bölgelerinin değerlendirilmesi amaçlanmıștır.

Yöntem: 2009 yılında Tokat ilinde 5,089 kiși kene enfestasyonu șikayeti ile hastanelere bașvurmuștur. Kene tutunması olan her hasta için sağlık personelleri tarafından doldurulan hastaların isim, yaș, cinsiyet, meslek, tarih, yașadığı alan, seyahat bilgisi ve ek notları içeren standart formlar incelenmiștir. Kene tutunma bölgeleri karın, kollar, koltuk altı, sırt, göğüs, baș ve boyun, kalça, bacaklar ve perine olmak üzere 9 gruba, hastaların yașları da 0-9, 10-19, 20-39, 40-64 ve $\geq 65$ olmak üzere 5 gruba ayrılarak incelenmiștir.

Bulgular: Bașvuran kișilerin büyük bir kısmında $(n=1,051, \% 23,3)$ kenelerin bacaklara tutunduğu tespit edilmiștir. 20-39 yaș grubundaki kișiler $(n=1.228, \% 27,24)$ kene tutunması oranının en yüksek olduğu grup olarak belirlenmiștir. Hastalardan 2.825 (\%62,67)'inin erkek, $1.683(\% 37,33)$ 'ının kadın olduğu tespit edilmiștir. Ayrıca, 2.740 (\%60.78) hastanın kırsal alanlarda, 1.768 (\%39,22) hastanın kentsel alanlarda yașadığı belirlenmiștir. İnsanlar üzerinden toplanan kenelerin tür teșhisleri yapıldığında, örneklerin Argas (1 tür), Dermacentor

'Department of Biology, Faculty of Science and Art, Gaziosmanpasa University, Tokat, Turkey ${ }^{2}$ Department of Public Health, Faculty of Medicine, Gaziosmanpasa University, Tokat, Turkey 
1 subspecies), Hyalomma (4 species), Ixodes (5 species) and Rhipicephalus (4 species).

Conclusion: In the present study, attachment sites of ticks and the demographic properties of patients were evaluated for the first time in Tokat province, a CCHF endemic region. In addition, it was reported people infestations by argas vespertilionis and Ixodes gibbosus ticks for the first time in Turkey.

Key Words: CCHF, human infestation, tick, Tokat, Turkey
(2 tür), Haemaphysalis (3 tür ve 1 alttür), Hyalomma (4 tür), Ixodes (5 tür) ve Rhipicephalus (4 tür) cinsleri içerisinde toplam 20 taksona ait olduğu belirlenmiștir.

Sonuç: Bu çalıșmayla birlikte, KKKA endemik Tokat bölgesinde kene enfestasyonu olan hastaların demografik özellikleri ve kenelerin tutunma bölgeleri ilk kez değerlendirilmiștir. Ayrıca, Türkiye'de insanların Argas vespertilionis ve Ixodes gibbosus türü keneler tarafından enfeste edildikleri ilk kez tespit edilmiștir.

Anahtar Kelimeler: KKKA, insan enfestayonu, kene, Tokat, Türkiye

\section{INTRODUCTION}

Ticks are one of the most encountered human parasites throughout the world. They may play an important role in the transmission of several zoonotic diseases to humans, such as CrimeanCongo Hemorrhagic Fever (CCHF), Lyme diseases, rickettsiosis, tick-borne encephalitis (TBE), ehrlichiosis and babesiosis (1-3). Every year thousands of people are affected by tick bites, while hundreds of them are infected with CCHF in Turkey (4-6). According to the Ministry of Health, 9,046 CCHF cases, and 440 deaths were recorded in Turkey between 2002 and 2014. Transmission of CCHF virus generally occurs through tick bites, however the virus can be transmitted by direct contact with blood, tissue or body fluids of patients or viremic animals $(7,8)$. Mortality rates may reach up to $40 \%$ and there is no currently safe and effective CCHF vaccine for humans (9).

In Turkey, CCHF virus has been detected from 7 hard ticks, namely Haemaphysalis concinna, Hyalomma anatolicum, Hyalomma marginatum, Hyalomma scupence, Rhipicephalus bursa, Rhipicephalus turanicus and Ixodes ricinus ticks (2), however it is believed that $H$. marginatum is playing a major role in the transmission of $\mathrm{CCHF}$ virus $(2,5$,
8, 10). The virus has been also detected in several small mammals such as hares and hedgehogs. In addition, antibodies against CCHF virus have been determined in the sera of domestic animals such as horses, donkeys, goats, cattle, sheep, and pigs (11).

Accurate and immediate tick removal from the human skin may be critical because transmission of tick-borne pathogens may occur during the first few hours of the tick attachment $(12,13)$. For example, Anaplasma and Rickettsia species are transmitted within 3-6 hours after the tick attachment, whereas Borrelia burgdorferi transmission can require 24-48 hours of feeding before a host is infected $(14,15)$. To the best of our knowledge, there is no information regarding the feeding time required for the transmission of CCHF virus from a tick to its host. On the other hand, it is known that certain tick-borne pathogens, such as TBE virus and Powassan virus, are transmitted to the host during the initial minutes of tick attachment or feeding $(15,16)$. Therefore, knowledge of attachment sites of ticks, duration of tick bites and demographic properties of patients may provide important information for an effective control of ticks and tick-borne diseases (17). 
Though many studies on the attachment sites of ticks, duration of tick bites and demographic properties of patients have been conducted $(17,18)$, there is limited information about these parameters in Turkey $(19,20)$. The aim of this study was to investigate the species composition of ticks collected from humans in Tokat province in 2009 and to compared the data with previous studies. In addition, attachment sites of ticks and demographic properties of patients should be evaluated for the first time in this CCHF endemic region.

\section{MATERIAL and METHOD}

Ticks were collected from humans in Tokat province and its districts in 2009. The ticks were removed from the skin of patients by physicians, nurses, or health technicians (non-attached ticks on the clothes or skin of humans were excluded). Collected ticks were placed in vials with $70 \%$ alcohol and sent to the Acarology Laboratory, Department of Biology, Gaziosmanpasa University (Tokat, Turkey) for identification. Ticks were identified to species based on morphological characteristics using taxonomic keys and descriptions of Filippova (21, 22), EstradaPeña et al. (23) and Apanaskevich and Horak (24).

A standard questionnaire including name, age, gender, profession, date, living area, and travel history of patients, was filled in for each patient with a tick bite. Questionnaires belonging to 4,508 patients were analyzed statistically, while 581 (11.41\%) questionnaires could not be evaluated due to missing data. Informed consent was obtained for all patients.

Chi-square test was used for comparisons of different groups. One variable was tested versus the others in two by two tables. A $p<0.05$ was considered as statistically significant. Odds ratios are shown with the corresponding 95\% confidence intervals. All statistical analyzes were performed using the SPSS software, Version 15.0 (SPSS Inc., USA).

\section{RESULTS \\ Demographic characteristics of the patients}

Out of 4,508 patients 2,825 (62.67\%) were male and $1,683(37.33 \%)$ were female. The number of patients living in rural areas was $2,740(60.78 \%)$ while of those living in urban areas was 1,768 (39.22\%). Patients living in urban areas were mainly infested in crop fields, gardens, picnic areas or farms. The youngest patient was a one-month-old while the oldest patient was 104-years-old (mean age: $32.71 \pm 20.56$ ). The largest proportion of tick bites were seen in 40-64 $(n=1,346,29.86 \%), 20-39(n=1,228,27.24 \%)$ and 10-19 $(n=949,21.05 \%)$ age groups (Table 1$)$.

\section{Species composition of ticks infesting humans}

In 2009, a total of 6,576 ticks were collected from 5,089 patients in Tokat province; however, only 4,508 patients gave accurate information for the questionnaires. A total of 20 tick taxa were identified, comprising 6 genera: Argas (1 species), Dermacentor (2 species), Haemaphysalis (3 species and 1 subspecies), Hyalomma (4 species), Ixodes (5 species) and Rhipicephalus (4 species) (Tables 2 and 3). Hyalomma marginatumcomprised $70.9 \%(n=3,198)$ of all ticks removed from patients. Other common ticks infesting humans were Rhipicephalus bursa $5.06 \%(n=228)$, Haemaphysalis parva $4.7 \%(n=212)$ and Rhipicephalus turanicus 3.88\% ( $\mathrm{n}=175)$ (Table 2).

\section{Attachment sites of ticks}

It was shown that $H$. marginatum infests legs 1.45 times (OR: $1.45, \mathrm{Cl}: 1.23-1.69$ ), and Hyalomma spp. nymphs infest perineum 2.14 times (OR: 2.14, $\mathrm{Cl}: 1.49$ - 3.00) more than other anatomical sites of patients. Haemaphysalis parva was mainly detected on head and neck area 6.24 times (OR: 6.24, Cl: 4.71 - 8.29), more than other anatomical sites, whereas Dermacentor marginatus was mainly detected on legs (1.79 times more than other parts of body) (OR: $1.79, \mathrm{Cl}: 1.17-2.71)$. Rhipicephalus turanicus was found on arms 2.82 times (OR: 2.82, Cl: 2.00 - 9.94) more than other parts of the body (Table 3 ). 0 
Table 1. Demographic characteristics of patients $(n=4508)$ with tick bites

\begin{tabular}{|c|c|c|c|c|c|}
\hline & Gender & Male & Female & Total & $\%$ \\
\hline \multirow{2}{*}{ 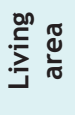 } & Rural & 1,713 & 1,027 & 2,740 & 60.78 \\
\hline & Urban & 1,112 & 656 & 1,768 & 39.22 \\
\hline \multirow{5}{*}{ 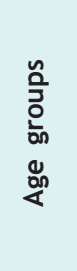 } & $0-9$ & 375 & 241 & 616 & 13.66 \\
\hline & $10-19$ & 666 & 283 & 949 & 21.05 \\
\hline & $20-39$ & 760 & 468 & 1,228 & 27.24 \\
\hline & $40-64$ & 776 & 570 & 1,346 & 29.86 \\
\hline & $\geq 65$ & 248 & 121 & 369 & 8.19 \\
\hline \multirow{9}{*}{ 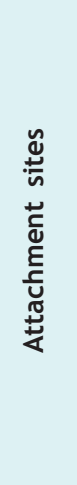 } & Abdomen & 267 & 189 & 456 & 10.12 \\
\hline & Arms & 432 & 170 & 602 & 13.35 \\
\hline & Axilla & 250 & 95 & 345 & 7.65 \\
\hline & Back & 236 & 151 & 387 & 8.58 \\
\hline & Chest & 110 & 77 & 187 & 4.15 \\
\hline & Head and neck & 404 & 373 & 777 & 17.24 \\
\hline & Hip & 125 & 120 & 245 & 5.44 \\
\hline & Legs & 693 & 358 & 1,051 & 23.31 \\
\hline & Perineum & 308 & 150 & 458 & 10.16 \\
\hline
\end{tabular}

\section{DISCUSSION}

Ticks are obligate blood-sucking ectoparasites of terrestrial vertebrate hosts. Most of the tick species have only limited host specificity; however it is known that there is a variety of factors which influence the host predilection of ticks (25). Although humans are accidental or incidental hosts of ticks (26), tick-bites are frequently seen among farmers, livestock handlers, s"hepherds, slaughterhouse workers, military personnel, picnickers, butchers, veterinarians, and naturalists $(6,8,20)$. The risk of exposure to tick bites is highest especially in edges of forest and in areas with tall grasses and bushes (27). The Tokat province is an endemic region for CCHF (2, $28,29)$ and every year over 5,000 tick bite cases have been reported from this province $(30,31)$. By the end of 2014, 1,908 CCHF cases and 85 deaths (4.45\%) were documented in this area. The CCHF cases/deaths were as follows: 2002-2003: 74/5, 2004: 101/4, 2005 : 71/4, 2006: 89/4, 2007: 139/7, 2008: 209/6, 2009: 211/10 2010: 162/6, 2011: 258/13, 2012: 168/3, 2013: 209/10, and 2014: 217/13). Bites of $H$. marginatum are common in this region, accounting for $50-70 \%$ of all tick bites $(28,32)$.

In a study contacted by Bursali et al. (30), a total of 5,999 ticks were collected from humans in Tokat province. Out of 5,999 adult ticks collected in 2008, 800 were identified to species level, while the remaining was identified to genus level. Initially, 24 hard ticks infesting humans were found in Tokat province; however, afterwards some specimens detected in their study were re-examined and the 
Table 2. Distribution of ticks species related to the age groups of patients

\begin{tabular}{|c|c|c|c|c|c|c|}
\hline Ticks / age groups & $0-9$ & $10-19$ & $20-39$ & $40-64$ & $\geq 65$ & Total \\
\hline Argas vespertilionis & & & & 1 & & 1 \\
\hline Dermacentor marginatus & 14 & 24 & 28 & 28 & 6 & 100 \\
\hline Dermacentor niveus & & 2 & 4 & 3 & & 9 \\
\hline Dermacentor nymphs & 10 & 5 & 6 & 4 & 1 & 26 \\
\hline Hyalomma aegyptium & 3 & 12 & 17 & 19 & 5 & 56 \\
\hline Hyalomma excavatum & 5 & 16 & 35 & 41 & 10 & 107 \\
\hline Hyalomma marginatum & 324 & 660 & 897 & 1,027 & 290 & 3,198 \\
\hline Hyalomma rufipes & & 1 & & 1 & & 2 \\
\hline Hyalomma larvae & 4 & & & & & 4 \\
\hline Hyalomma nymphs & 59 & 38 & 57 & 55 & 21 & 230 \\
\hline Haemaphysalis erinacei taurica & 4 & & 5 & 2 & & 11 \\
\hline Haemaphysalis parva & 89 & 44 & 50 & 25 & 4 & 212 \\
\hline Haemaphysalis punctata & 12 & 13 & 11 & 17 & 4 & 57 \\
\hline Haemaphysalis sulcata & 2 & & 2 & & & 4 \\
\hline Ixodes frontalis & & & 1 & & & 1 \\
\hline Ixodes gibbosus & 2 & 4 & 1 & 3 & & 10 \\
\hline Ixodes laguri & 1 & & 1 & & & 2 \\
\hline Ixodes redikorzevi & 3 & 2 & 9 & 12 & 2 & 28 \\
\hline Ixodes ricinus & 5 & 6 & 7 & 11 & 6 & 35 \\
\hline Rhipicephalus annulatus & 3 & & 2 & 3 & & 8 \\
\hline Rhipicephalus bursa & 39 & 60 & 62 & 53 & 14 & 228 \\
\hline Rhipicephalus sanguineus & 2 & 1 & & & & 3 \\
\hline Rhipicephalus turanicus & 34 & 61 & 33 & 41 & 6 & 175 \\
\hline Rhipicephalus nymphs & 1 & & & & & 1 \\
\hline Total & 616 & 949 & 1,228 & 1,346 & 369 & 4,508 \\
\hline
\end{tabular}

total number of ticks infesting humans was corrected as 18 (32). In the present study, a total of 20 tick species infesting humans were identified. It was also found that $62.67 \%$ of the patients were males, while $37.33 \%$ were females. Similar rates have been found by Sumer (33) (51.8\% and $48.2 \%$, respectively); by Erol et al. (20) (54.5\% and 45.5\%, respectively) and by Over et al. (34) (52.1\% and 47.9\%, respectively). Previous studies reported that tick bites in children are more common than adolescents, adults and older person $(35,36)$. In this study, however, we observed that the largest proportion of tick bites were seen in 40-64 age groups $(n=1,346,29.86 \%)$, followed by 20 39 years old age group $(n=1,228,27.24 \%)$.

Our findings are partially consistent with studies of Erol et al. (20) and Sumer (33). We believe that these findings are most likely associated with the number of residents of Tokat Province in the 40-64 age groups or their intensive agricultural activities. 
Table 3. Attachment sites of ticks on the patients

\begin{tabular}{|c|c|c|c|c|c|c|c|c|c|c|}
\hline Ticks/Attacment sites & Abdomen & Arms & Axilla & Back & Chest & Head and neck & Hip & Legs & Perineum & Total \\
\hline Argas vespertilionis & & & & & & 1 & & & & 1 \\
\hline $\begin{array}{l}\text { Dermacentor } \\
\text { marginatus }\end{array}$ & 7 & 22 & 1 & 5 & 2 & 20 & 3 & 35 & 5 & 100 \\
\hline Dermacentor niveus & 3 & 1 & & & & 2 & 1 & 2 & & 9 \\
\hline Dermacentor nymphs & 2 & 3 & 3 & & 2 & 7 & 2 & 3 & 4 & 26 \\
\hline Hyalomma aegyptium & 4 & 3 & 2 & & & 2 & 3 & 40 & 2 & 56 \\
\hline Hyalomma excavatum & 8 & 19 & 12 & 8 & 2 & 10 & 2 & 34 & 12 & 107 \\
\hline Hyalomma marginatum & 343 & 377 & 264 & 296 & 136 & 428 & 197 & 804 & 353 & 3,198 \\
\hline Hyalomma rufipes & & & & 1 & & & & 1 & & 2 \\
\hline Hyalomma larvae & & & 1 & & & 3 & & & & 4 \\
\hline Hyalomma nymphs & 13 & 31 & 29 & 16 & 20 & 43 & 8 & 27 & 43 & 230 \\
\hline $\begin{array}{l}\text { Haemaphysalis erinacei } \\
\text { taurica }\end{array}$ & 1 & 4 & 1 & & & 4 & & 1 & & 11 \\
\hline Haemaphysalis parva & 14 & 29 & 8 & 10 & 7 & 113 & 3 & 19 & 9 & 212 \\
\hline $\begin{array}{l}\text { Haemaphysalis } \\
\text { punctata }\end{array}$ & 1 & 10 & 1 & 9 & 2 & 23 & 2 & 8 & 1 & 57 \\
\hline Haemaphysalis sulcata & 1 & 1 & & & & 1 & & 1 & & 4 \\
\hline Ixodes frontalis & & & & & & & & 1 & & 1 \\
\hline Ixodes gibbosus & & 4 & & & 1 & 4 & & & 1 & 10 \\
\hline Ixodes laguri & & 1 & & & & & & 1 & & 2 \\
\hline Ixodes redikorzevi & 1 & 3 & 3 & & 2 & 9 & 1 & 6 & 3 & 28 \\
\hline Ixodes ricinus & 4 & 11 & & 3 & 4 & 2 & 2 & 7 & 2 & 35 \\
\hline $\begin{array}{l}\text { Rhipicephalus } \\
\text { annulatus }\end{array}$ & & 3 & & & & 4 & 1 & & & 8 \\
\hline Rhipicephalus bursa & 34 & 29 & 14 & 26 & 3 & 49 & 18 & 41 & 14 & 228 \\
\hline $\begin{array}{l}\text { Rhipicephalus } \\
\text { sanguineus }\end{array}$ & & & & & & 2 & & & 1 & 3 \\
\hline Rhipicephalus turanicus & 20 & 51 & 6 & 13 & 6 & 49 & 2 & 20 & 8 & 175 \\
\hline Rhipicephalus nymphs & & & & & & 1 & & & & 1 \\
\hline Total & 456 & 602 & 345 & 387 & 187 & 777 & 245 & 1,051 & 458 & 4,508 \\
\hline
\end{tabular}

Ticks may be found on several anatomical sites of humans but mainly on and around the head and neck area as well as in perineum (37). In the present study it was observed that most of the ticks were found on legs $(n=1,051,23.31 \%)$, followed by head and neck $(n=777$, $17.24 \%)$ and arms $(n=602,13.35 \%)$. These findings are partially consistent with studies of Gunduz et al (19), Erol et al. (20) and Sumer (33).
There are several studies about the evaluation of tick bites from the different parts of Turkey $(19,20$, 33 ); however, only limited numbers of patients with tick bites were evaluated, e.g., 67 cases in Gunduz et al., (19), 168 cases in Sumer, (33), 161 cases in Erol et al. (20), and 273 cases in Over et al. (34). Only, in a recent study by Kar et al. (38), 1,816 patients were analyzed from the Istanbul province for tick bites. The authors reported that predilection sites of attachment 
for Hyalomma aegyptium and D. marginatus were the extremities and scalp, respectively, while $H$. marginatum and Ixodes ricinus were found mainly on the trunk. In the present study, D. marginatus, $H$. excavatum, and $H$. marginatum ticks were mainly found on legs, $H$. parva and $R$. bursa on head and neck, and $R$. turanicus on arms. Argas vespertilionis and Ixodes gibbosus ticks were reported on humans for the first time in Turkey.

\section{CONCLUSION}

In the present study, we found that 20 tick taxa (19 species and 1 subspecies) can be infest on humans in the study area. Results of this study also showed that preferred attachment sites of ticks may be changed by demographic properties and age groups of patients. Tick bites are one of the important public health problems in Turkey, especially in CCHF endemic regions. Accurate and immediate tick removal from the human skin is very crucial to prevention of tickborne diseases. Despite farmers, livestock handlers, shepherds, slaughterhouse workers, military personnel, picnickers, butchers, veterinarians, and naturalists are at increased risk of tick bites, and subsequently tickborne disease, anyone who spends any amount of time outdoors in suitable tick habitats, can potentially be exposed to ticks.

For those people it is advised to: (I) wear protective and light colored clothing; (II) use of repellents containing 20-30\% DEET (N, N-diethyl-m-toluamide) on the exposed skin areas or $0.5 \%$ permethrin on clothing; (III) regularly check clothing and skin and promptly remove attached ticks; and (IV) avoid habitats where ticks are abundant and most active $(39,40)$.

\section{ACKNOWLEDGMENTS}

We are mostly grateful to Dr. Yalcin Onder and Dr. Soner Sorhan (Department of Public Health, Gaziosmanpasa University, Turkey) for their valuable comments on this paper. This study has been partially supported by Gaziosmanpasa University Scientific Research Fund (Project No: 2013/42).

\section{REFERENCES}

1. Williamson PC, Billingsley PM, Teltow GJ, Seals JP, Turnbough MA, Atkinson SF. Borrelia, Ehrlichia and Rickettsia spp. in ticks removed from persons, Texas, USA. Emerg Infect Dis, 2010; 16: 441-6

2. Tekin S, Bursali A, Mutluay N, Keskin A, Dundar E. Crimean-Congo hemorrhagic fever virus in various ixodid tick species from a highly endemic area. Vet Parasitol, 2012; 186: 546-52.

3. Oteo JA, Portillo A. Tick-borne rickettsioses in Europe. Ticks Tick Borne Dis, 2012; 3: 271-8.

4. Gargili A, Kar S, Yılmazer N, Cerit C, Sonmez G, Sahin F, Alp H, Vatansever Z. Evaluation of ticks biting humans in Thrace Province, Turkey. Kafkas Univ Vet Fak Derg, 2010; 16: 141-6.

5. Bursali A, Tekin S, Keskin A, Ekici M, Dundar E. Species diversity of ixodid ticks feeding on humans in Amasya, Turkey: seasonal abundance and presence of Crimean-Congo hemorrhagic fever virus. J Med Entomol, 2011; 48: 85-93.

6. Bakirci S, Aysul N, Eren H, Unlu AH, Karagenc T. Diversity of ticks biting humans in Aydın province of Turkey. Ankara Univ Vet Fak Derg, 2014; 61: 93-8.
7. Whitehouse CA. Crimean-Congo hemorrhagic fever Antiviral Res, 2004; 64: 145-60.

8. Yilmaz GR, Buzgan T, Irmak H, Safran A, Uzun R, Cevik MA, Torunoglu MA. The epidemiology of Crimean-Congo hemorrhagic fever in Turkey, 20022007. Int J Infect Dis, 2009; 13: 380-6.

9. World Health Organization (WHO) 2015. CrimeanCongo haemorrhagic fever, Available from http:// www.who.int/mediacentre/factsheets/fs208/en.

10. Tonbak S, Aktas M, Altay K, Azkur AK, Kalkan A, Bolat Y, Dumanli N, Ozdarendeli A. CrimeanCongo hemorrhagic fever virus: genetic analysis and tick survey in Turkey. J Clin Microbiol, 2006; 44: $4120-4$

11. Hoogstraal H. The Epidemiology of Tick-Borne Crimean-Congo Hemorrhagic Fever in Asia, Europe, and Africa. J Med Entomol, 1979; 15: 307-417.

12. Piesman J. Transmission of Lyme disease spirochetes (Borrelia burgdorferi). Exp Appl Acarol, 1989; 7: 71-80 
13. Otranto D, Dantas-Torres F, Giannelli A, Latrofa MS, Cascio A, Cazzin S, Ravagnan S, Montarsi F, Zanzani SA, Manfredi MT, Capelli G. Ticks infesting humans in Italy and associated pathogens. Parasit Vectors, 2014; 7: 328

14. des Vignes F, Piesman J, Heffernan R, Schulze TL, Stafford KC 3rd, Fish D. Effect of tick removal on transmission of Borrelia burgdorferi and Ehrlichia phagocytophila by Ixodes scapularis nymphs. J Infect Dis, 2001; 183: 773-8

15. Ebel GD, Kramer LD. Duration of tick attachment required for transmission of Powassan virus by deer ticks. Am J Trop Med Hyg, 2004; 71(3): 268-71

16. Lane RS. Competence of ticks as vectors of microbial agents with an emphasis on Borrelia burgdorferi. In: Sonenshine, D.E., Mather, T.N., (Eds.), Ecological dynamics of tick-borne zoonoses. New York: Oxford University Press, 1994; 45-67

17. Slaff M, Newton NH. Location of tick (Acari: Ixodidae) attachment sites on humans in North Carolina. J Med Entomol, 1993; 30: 485-8.

18. Felz MW, Durden LA. Attachment sites of four tick species (Acari: Ixodidae) parasitizing humans in Georgia and South Carolina. J Med Entomol, 1999; 36: 361-4

19. Gunduz A, Turkmen S, Turedi S, Nuhoglu I, Topbas M. Tick attachment sites. Wilderness Environ Med, 2008; 19: 4-6

20. Erol S, Yenisolak A, Toros GY, Albayrak A. Evaluation of the tick bites in a Crimean-Congo haemorrhagic fever (CCHF) endemic area in Turkey. Turk J Med Sci, 2011; 41: 131-6

21. Filippova NA. Ixodid ticks (Ixodinae). Fauna USSR New Ser. 4 (4), Moscow, Leningrad: Nauka Publishing House, 1977

22. Filippova NA. Ixodid ticks of subfamily Amblyomminae. Fauna of Russia and neighbouring countries. St. Petersburg: Nauka Publishing House, 1997

23. Estrada-Peña A, Bouattour A, Camicas JL, Walker AR. Ticks of veterinary and medical importance: the mediterranean basin. A guide of identification of species. Zaragoza: University of Zaragoza Press, 2004

24. Apanaskevich DA, Horak IG. The Genus Hyalomma Koch, 1844: V. re-evaluation of the taxonomic rank of taxa comprising the $\mathrm{H}$. (Euhyalomma) marginatum Koch complex of species (Acari: Ixodidae) with redescription of all parasitic stages and notes on biology. Int J Acarol, 2008; 34: 13-42

25. Hoogstraal H, Aeschlimann A. Tick-host specificity. Bull Societe Entomol Suisse, 1982; 55: 5-32

26. Dantas-Torres F, Chomel BB, Otranto D. Ticks and tick-borne diseases: a One Health perspective. Trends Parasitol, 2012; 28: 437-46
27. Vatansever Z, Uzun R, Estrada-Pena A, Ergonul 0 . Crimean-Congo hemorrhagic fever in Turkey. In: Ergonul, O., Whitehouse, C.A., (Eds.,), CrimeanCongo Hemorrhagic Fever: A Global Perspective. Netherlands: Springer, 2007: 59-74

28. Gunes T, Poyraz 0 , Vatansever $Z$. CrimeanCongo hemorrhagic fever virus in ticks collected from humans, livestock, and picnic sites in the hyperendemic region of Turkey. Vector Borne Zoonotic Dis, 2011; 11(10): 1411-6.

29. Duygu F, Kaya T, Baysan P. Re-evaluation of 400 Crimean-Congo hemorrhagic fever cases in an endemic area: is ribavirin treatment suitable? Vector Borne Zoonotic Dis, 2012; 12: 812-6

30. Bursali A, Tekin S, Orhan M, Keskin A, Ozkan M. Ixodid ticks (Acari: Ixodidae) infesting humans in Tokat province of Turkey: species diversity and seasonal activity. J Vector Ecol, 2010; 35: 180-6

31. Keskin A. Systematic investigation of hard ticks (Acari: Ixodidae) parasitizing humans in Tokat region and determination of rickettsiae in these ticks. PhD dissertation. Tokat: Gaziosmanpasa University Institute of Science, 2014

32. Bursali A, Keskin A, Tekin S. A review of the ticks (Acari: Ixodida) of Turkey: species diversity, hosts and geographical distribution. Exp Appl Acarol, 2012; 57: 91-104

33. Sumer A. Kene Isırığı Nedeniyle Kaș Devlet Hastanesi Acil Servisine Bașvuran Hastaların Değerlendirilmesi. Kafkas Univ Vet Fak Derg, 2010; 16: $49-53$

34. Over L, Inceboz T, Yapar N, Bakirci S, Gunay T, Akisu C. Dokuz Eylül Üniversitesi Hastanesi'ne Kene Tutması Yakınması ile Bașvuran Olguların Araștırılması. Turkiye Parazitol Derg, 2012; 36: 75-81

35. Falco RC, Fish D, Piesman J. Duration of tick bites in a Lyme disease-endemic area. Am J Epidemiol, 1996; 143: 187-92

36. Robertson JN, Gray JS, Stewart P. Tick bite and Lyme borreliosis risk at a recreational site in England. Eur J Epidemiol, 2000; 16: 647-52

37. Parola P, Raoult D. Ticks and tick-borne bacterial diseases in humans: an emerging infectious threat. Clin Infect Dis, 2001; 32: 897-928

38. Kar S, Dervis E, Akın A, Ergonul O, Gargili A. Preferences of different tick species for human hosts in Turkey. Exp Appl Acarol, 2013; 61: 349-55

39. Stafford KC 3rd. Tick Management Handbook: An Integrated Guide for Homeowners, Pest Control Operators, and Public Health Officials for the Prevention of Tick-Associated Disease. Connecticut: The Connecticut Agricultural Experimental Station, 2007

40. Piesman J, Eisen L. Prevention of Tick-Borne Diseases. Annu Rev Entomol, 2008; 53: 323-43. 